\title{
DEVELOPMENT OF BUSINESS MODELS OF LOW-COST AIRLINES
}

\author{
Andrija Vidović ${ }^{1}$, Igor Štimac ${ }^{2}$, Damir Vince ${ }^{3}$ \\ ${ }^{1}$ University of Zagreb, Faculty of Transport and Traffic Sciences, Department of Air Transport, \\ Vukelićeva 4, 10000 Zagreb, Croatia \\ ${ }^{2,3}$ Zagreb Airport Ltd., Rudolfa Fizira 1, 10150 Zagreb, Croatia
}

Received 4 March 2013; accepted 22 March 2013

\begin{abstract}
The global economic crisis that affects all industries, including the aviation industry, has forced airlines to adjust their business models to existing market conditions. Low-cost airlines, which till the onset of economic crises in most cases followed the base low-cost business model, have adapted their business model in such a way that they have implemented segments of traditional airlines business models and thus created a hybrid between traditional and low-cost business models. This paper analyses to which extent low-cost airlines adjust their business model to the hybrid business model.
\end{abstract}

Keywords: low-cost airlines, business model, hybrid strategy.

\section{Introduction}

Low-cost airlines (LCA) have revolutionized the medium-haul market as a result of liberalization and deregulation of the aviation market in Europe in a way that they provide air travel at significantly lower prices. The concept was originally developed in the USA in the 70's of the last century, after which in the 1990's it has spread first through Europe and finally in the rest of the world. The business model by which the LCA had up to $50 \%$ lower operating costs compared to full network service airlines (FNSA) is no longer achievable, due to the global economic crisis and higher fuel costs, but also because FNSA adjusted their business models to the existing market conditions. In an effort to maintain market share at the medium-haul markets, FNSA offer new products, reorganize and rationalize their operations, reduce costs and fees for their services. As the air transport industry dynamics has changed, so have business strategies of LCA.
The result is a change or an improvement of business models of LCA and FNSA.

\section{Airline Business Models}

In its beginning, LCA business model was based on fundamentally different postulates in relation to the business model of traditional airlines. There are three basic airlines' strategies: FNSA, which operate on a broad geographic coverage; LCA, which operate on mediumhaul routes; and charter airlines which focus on long-haul sectors. This classification can be extended with the segment of cargo airlines, but this paper will focus on the passenger airlines.

Over the recent years, there has been an increasing trend of mergers and acquisitions of airlines, the creation of different models of alliances and the mixing of different business models. While until recently, it was clear which business model provides what level of service, today it is difficult to

\footnotetext{
${ }^{1}$ Corresponding author: avidovic@fpz.hr
} 
differentiate which airline belongs to which category, and that has become especially complicated with the emergence of hybrid carriers that have further expanded their offer in the aviation market. For that reason, in this paper the specifities of different business models will be analyzed as well as the possible reasons for the modification of these models. In the following sections, a brief sketch of the specifities of three fundamental business models of passenger airlines will be presented.

\subsection{Full Network Service Airlines}

Full netvork service airlines are airlines that focus on providing a wide range of services, including multiple passenger classes inside an aircraft cabin and the possibility of connected flights. Since most FNSA operate a hub-and- spoke model, these airlines are also called hub-and-spoke airlines. In most European countries the national carriers are typical representatives of traditional airlines. For example, Air France/KLM, Lufthansa, British Airways, Austrian Airlines, LOT, etc. While most of the former national carriers in larger EU countries are now partially or completely privatized, some states, especially smaller, still have a national carrier wholly owned by the state. Fig. 1 shows the degree of the privatization of Europe's largest traditional airlines. Outside the EU, the number and structure of ownership varies from country to country. The USA is the only country in which a very large number of independent, fully privatized traditional airlines operate. Unlike the USA, in many countries of Asia and Africa, only one state-owned traditional airline operates.

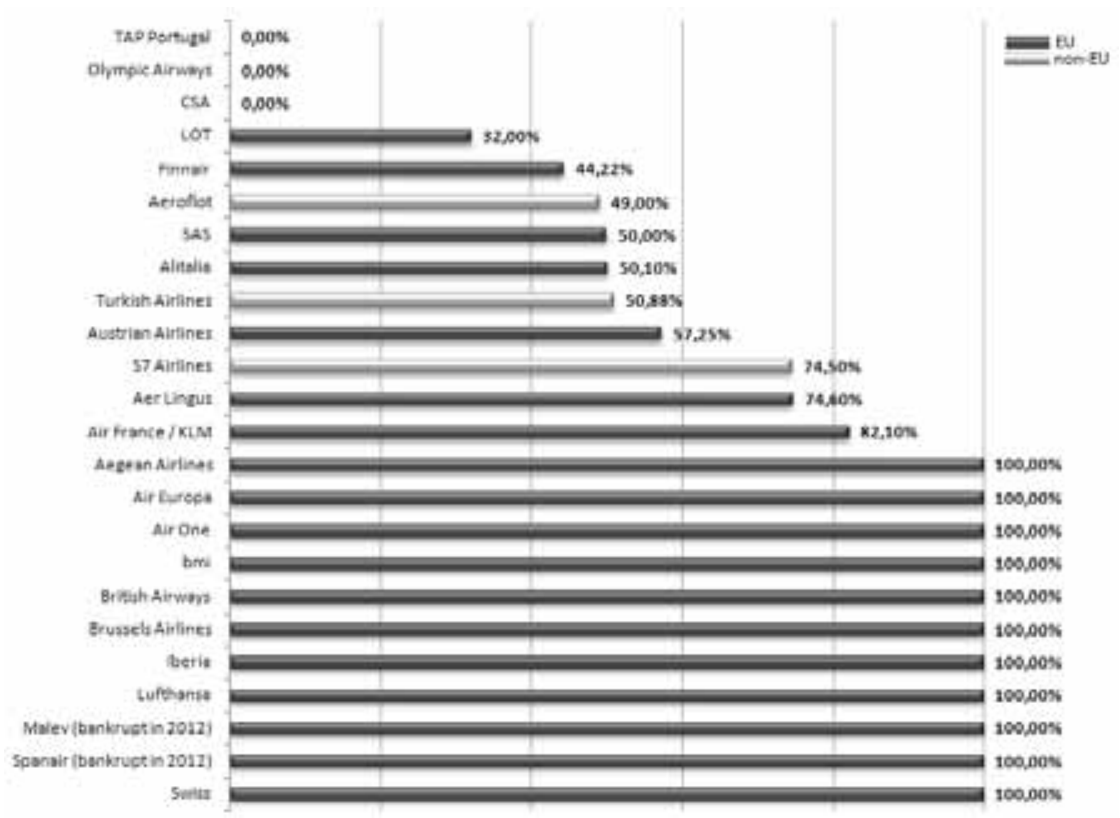

Fig. 1.

Top 25 European Traditional Airlines by Criterion Seats per Week - Degrees of Privatization Source: DLR (2008) 
Traditional airlines are characterised by the following aspects:

- Fleet: different aircraft models, from small regional to large wide-body aircraft;

- Geographical coverage of network: domestic, intra-European and longhaul flights, with a focus on the respective home country;

- Structure of network: hub-and-spoke network often complemented by the selected decentralized non-hub flights;

- Schedules: a wide range of destinations offered via the respective hub, high frequency of flights;

- The range of services: 2-4 passenger classes, high level of service in first and business class;

- Prices: complex yield management, a large price range.
There are several comercial and legal reasons for FNSA to use hub-and-spoke networks. As the number of destinations is growing, so does the aircraft load factor, resulting in lower unit costs per passenger. If higher demand justifies the use of larger aircraft, the unit costs per seat also drop. This phenomenon explains why the largest aircraft, the Boeing 747 and Airbus 380, operate mainly between hubs where traffic volumes are very high. From marketing and strategic point of view, the bundling and redistribution of incoming and outgoing passengers at hubs allows airlines to connect a larger number of destinations. In addition, the airlines that use hubs have a tendency of gaining market power at their respective hubs, which allows them less competition and to charge the so-called hub premium, e.g. higher fares for transfer passengers flying from hubs than for transfer passengers and passengers who fly on similar routes that do not include airlines

\section{Table 1}

Cost Distribution of Low-Cost Airlines on Short-Haul Flights in Relation to Traditional Operators

\begin{tabular}{|l|c|c|}
\hline & Cost reduction (\%) & Cost per seat \\
\hline Traditional scheduled airline & & 100 \\
\hline Low-cost airline & & \\
\hline Operating advantages: & & \\
\hline Higher seating density & -16 & 84 \\
\hline Higher aircraft utilisation & -2 & 82 \\
\hline Lower flight and cabin crew costs & -3 & 79 \\
\hline Use cheaper secondary airports & -4 & 75 \\
\hline Outsourcing maintenance/single aircraft type & -2 & 73 \\
\hline Product/service features: & & \\
\hline Minimal station costs and outsourced handling & -7 & 66 \\
\hline No free in-flight catering, fever passenger services & -5 & 61 \\
\hline Differences in distribution: & & 55 \\
\hline No agents or GDS commissions & -6 & 52 \\
\hline Reduced sales/reservation costs & -3 & 49 \\
\hline Other advantages: & & 49 \\
\hline Smaller administration and fewer staff/offices & -3 & \\
\hline Low-cost compared to traditional airline & & \\
\hline
\end{tabular}

Source: Doganis (2007) 
hub. In Europe this aspect is of a special importance due to the capacity limitations of largest hubs and slot allocation which prevent further entry of new carriers.

The biggest disadvantages of hub-and-spoke model are the complexity of connecting flights in the given time frame and high capacity utilization during peak periods. As the demand for point-to-point flights between most destinations worldwide is usually low, large hubs are the only way that air services can be offered between most destinations. The legal reasons for the implementation of hub-andspoke model in the past were strict bilateral air service agreements (ASAs), according to which only one or a small number of airports in each included were determined as landing points. Strictly bilateral agreements are still common between the EU member states and most countries in Africa, Asia, the Middle East and South America.

\subsection{Low-Cost Airlines}

LCA focus on reducing costs in order to implement a leading price strategy on markets they serve. Table 1 shows which strategic measures lead to the reduction in unit costs.

The usage of younger homogeneous mediumsized fleet (usually Boeing 737-700/800 or Airbus 319/320) usually results in lower fuel, maintenance and personnel costs and in the case of large aircraft orders in lower capital costs. Higher seat density in aircraft results in lower unit costs for all cost categories, such as fixed costs (including the costs of the ATC). The only variable the "in-flight seating" costs (additional costs associated with fuel) increase with the growth of passengers on board. Delays can be reduced by using smaller, capacity uncognested, airports and by focusing on point-to-point flights without connections, which allow LCA to maximize daily block-hours, and by that the utilization of aircraft (Fig. 2).

The "free-seating" philosophy also contributes to the reduction of operating costs because it encourages passengers to board the plane earlier and thus additionaly reduce delays. Besides uncognestion, smaller airports usually charge lower fees than larger established airports and

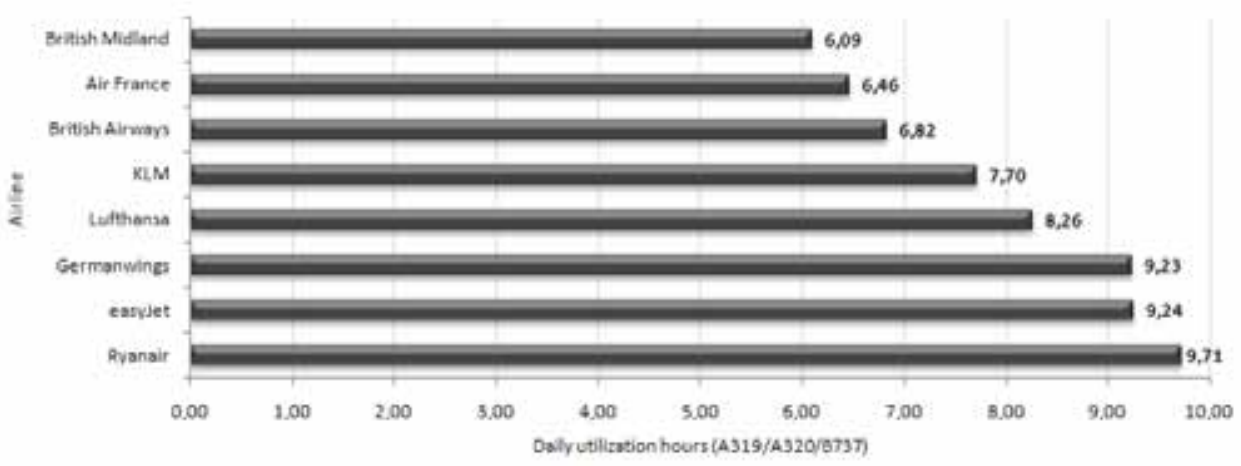

Fig. 2.

Daily Aircraft Utilization

Source: DLR (2008) 
are willing to co-finance the promotion of new routes. Finally, the unit costs are reduced by direct selling of tickets online, higher density seating, as well as by eliminating all forms of free in-flight services such as catering, entertainment during the flight, magazines, etc.

The LCA price policy is usually very dynamic. For example, they offer significant discounts if a person buys a ticket well in advance, which leads to the opening of markets for passengers who would otherwise travel by other transport means. LCA generate additional revenues by selling products and services during the flight and on their websites, for example, fees for check-in baggage and credit card payment.

However, not all LCA have applied all the above listed aspects of savings. EasyJet, for example, is among those LCA that operate from major hubs (Amsterdam, Madrid, Munich, Paris CDG, etc.) and uses the CRS (Computer Reservation System). Germanwings is one of the few LCA to have introduced a frequent flyer program (FF), although travelers have to pay a registration fee to cover administrative costs. FlyBe and Intersky have applied the elements of the lowcost strategy to the regional market. Ryanair and Wizz Air are typical representatives of the original low-cost model. They still mainly use smaller airports and charge fees for baggage handling. Air Berlin, the second largest carrier in Germany, operates a business model that is a combination of the typical elements of the LCA, FNSA and charter business model. Air Berlin is a typical example of a hybrid airline.

While the LCA in past were initially focused on short-haul flights, today they increasingly expand their services to medium-haul markets. The main reasons for the entering in mediumhaul market are the increased competition on the existing routes and new ASAs between Europe and third countries. For example,
Ryanair and EasyJet started their flights from airports in Western Europe to Morocco after the new agreement on air transport between the EU and Morocco had become effective.

This is one example of the positive effects that LCA have on deregulation of the market and competition, as well as the benefits for the users of air services. In general, the increasing competition and declining prices of services could be seen on all routes and pairs of cities operated by LCA. In addition, the presence of the LCA at uncognested regional airports contributes the development of the regional economy and in some cases helps the region to maintain or reinforce air services when, for example, the primary airport in the region has a capacity limit without further growth potential. The examples of this are the Rhine/ Ruhr region in Germany and the London area, in which a significant growth of secondary airports (Cologne, Dortmund, Stansted and Luton) partially helped relieve capacity restrictions at the airports of Dusseldorf and Gatwick/Heathrow. From the perspective of environmental protection, LCA, despite having a significant contribution to the absolute growth in the aviation sector, have relatively low $\mathrm{CO}_{2}$ emissions per passenger kilometre (RPK) since they operate a modern and fuel-efficient fleet with more seats than their competitors.

\subsection{Charter Airlines}

Charter airline is a broad term for carriers that focus on the transportation of tourists and are often referred to as "holiday" or "leisure" airlines. In the past, the term "charter airline" was frequently used because most of the holiday flights were not sold directly by the carrier but included in the charter packages offered by tour operators. Today, many charter flights operate as scheduled, although they often have only a seasonal caracter. 
Charter airlines achieve low costs per seat-mile by focusing on the direct point-to-point flights, using a homogeneous fleet of medium-sized and large aircraft with a high seating density. Charter airlines typically offer a full service on the flight (food, beverages, entertainment, newspapers, magazines, etc.). The main differences between LCA and charter airlines are reflected in the flight network and yield management. While LCA yield management follows an increasing price curve, leisure airlines usually charge average prices amended by additional seasonal surcharges or discounts by occasional promotional fares. As tourists usually stay on a vacation for a week or longer, the focus is on the concentration of demand for a particular destination on a few flights per week, while LCA on most routes usually offer at least one daily frequency. Most tourists are prepared to travel long distances to the departure airports and this allows airlines to concentrate passenger flows on flights from several departure airports. Several airlines which concentrate on the ethnic market, e.g. from Germany to Turkey, are acting in a similar manner.

\section{The Evolution of Low-Cost Model}

Since its appearance on the European market in the mid 90's of the last century the market share of LCA has grown rapidly, and traditional airlines have been forced to change and adjust their business strategies at the medium-haul market. Currently, there are more than 40 LCA operating in Europe and they generate more than $36 \%$ of total passenger traffic (Fig. 3) and $23 \%$ of total Instrumental Flight Rules (IFR) operations (Vidović et al., 2012). However, their market share has no longer as significant growth as it was the case a few years ago.

The base model of low-cost airlines by which they achieve significantly lower operational costs is based on the characteristics listed in Table 1, of which the most important are the following: the focus on minimal costs and prices and maximum efficiency, the use of younger fleet composed mostly of one aircraft model, the use of secondary and uncognested regional airports, point-to-point network of flights, direct ticket sales (mostly online), one passenger class inside the aircraft cabin, no in-flight service, etc.

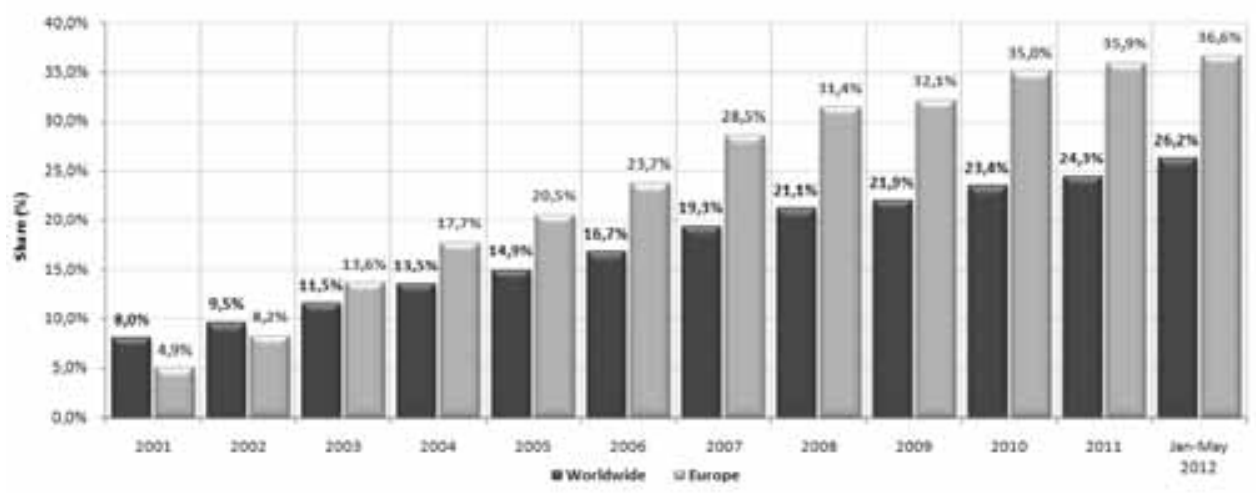

Fig. 3.

LCA Market Share According to Available Seats - the Worldwide in Relation to Europe (2001 - 2012)

Source: CAPA (2013) 
However, over the last years the border that separated the business strategies of FNSA and LCA becomes thinner. Today the base low-cost model is applied by several LCA in the world. Mixing of business strategies is present in the majority of airlines who were categorized as LCA in the past and should now be properly classified as hybrid airlines.

The four largest LCA markets in Europe (UK, Spain, Germany and Italy) represent more than two thirds of the total number of transport passengers and more than half of the destinations offered by the LCA. The growth of the seat capacity in the year 2010 on these markets was $1,8 \%$ compared to an average growth of 4,5\% in the rest of Europe, which implies greater maturity of these markets. At the same time, the number of routes offered in these markets grew by 9,4\% (Klophaus et al., 2012). Major expansion of routes combined with a modest increase in capacity reflects the business strategy of many European LCA, especially air carriers such as Ryanair and EasyJet, which are developing new routes rather than increasing the frequency of flights to the existing destinations.

Due to the large differences in the operating costs in the past, which were up to $50 \%$ lower for LCA when compared to FNSA, the space for further cost reductions is very limited. The reason for reducing the difference in the cost between the LCA and FNSA lies in a few fundamental factors. Dynamic aviation market and the increasing share of LCA led the FNSA to adjust their business models in order to minimize the differences in costs. Therefore, LCA were also forced to change their basic lowcost models. Although the price of the service will remain the main competitive factor in the selection of the operator, it is not the only factor that LCA should take into consideration when developing a new business strategy.
LCA are now focusing on other areas as well, such as mergers with other airlines, low maintenance costs while compensating the increasing cost of fuel and aircraft, the integration of new services into the existing model, improving customer service, experimenting with long-haul flights, etc. The three main reasons for the reduction of the differences in the costs and challenges that LCA are facing are: increasing fuel prices, increased costs of airport services, especially for those carriers that use the services of primary airports and finally, the increasing competition in the aviation market (Hamsathul, 2012).

The space for further cost reductions is possible only for those low-cost airlines which do not follow the postulate of the base low-cost model. For example, if airlines which have different models of aircraft in their fleet moved to the same type of aircraft (or same aircraft family, such as the A320 aircraft family, consisting of A318, A319, A320 and A321), they would be able to reduce additionally the operating costs related to training and licensing of aircraft crew and aircraft maintenance personnel. Ryanair is an example of LCA which in its fleet has only B737-802 aircraft, while most other carriers operate with two or more families of aircraft. The fleet is more homogeneous when there is a smaller impact on the increasement in total operating expenses. However, it is estimated that if the aircraft fleet is comprised of more than $75 \%$ of the same family aircraft, it can be considered as sufficiently homogeneous for the LCA (Klophaus et al., 2012). All lower values regarding aircraft fleet point to the hybrid business model.

Another segment in which individual LCA can make additional savings is the usage of strictly secondary and non- congested regional airports, i.e. the avoidance of the use of more expensive services in primary airports. There is 
no exact definition of what the real secondary airports are. One of the definitions says that secondary airports are those airports that have less than 2 million annual passenger traffic, while other definitions classify them as those airports where there is no landing of the national carrier's aircraft with at least 100 seats. For the LCA it can be considered to be satisfactory when the percentage of such airport is at least $50 \%$ of the total number of airports they serve.

The third factor in which LCA can achieve additional savings is the sales network. LCA, such as Ryanair, which operate on a base low-cost model, do not use intermediaries such as travel agencies or a global reservation system, but their services are offered via their own website. While some travel agents offer a sale of the Ryanair flights through the operator's website for the commission, it may be considered that this sale is not really a deviation from the principle of direct sales; the carrier is not directly involved in the sales process. Furthermore, on the websites of some agencies the flight offers are displayed, and after clicking on those links, the users will be forwarded directly to the websites of the carrier for the process of buying tickets. If an LCA tariff being offered over the internet does not include a return ticket at a lower price than the sum of the two one-way tickets, it can be considered that the carrier operates at a base low-cost model. The service of Ryanair can be taken as an example, which does not offer more than one tariff for the time of the flight booking.

However, most LCA have been offering lately their sales service via agencies and global distribution system in addition to the sales on their own websites. Unlike Ryanair, they offer more tariffs per flight. The highest prices usually include additional services such as extra baggage, choice of seats, change of a flight date without the extra charge, etc. If all the seats on the short-haul flight are within one passenger class, this is seen as a one-class flight. If the passengers in the first rows and in the rows near the exits have the possibility of making a reservation and speed boarding, this is also considered compatible for this criterion. For example, Germanwings does not meet the one-passenger class criterion (they offer economy and premium economy class) since the seat with more leg space are found in the forst ten rowns in the aircraft, which means that they deliberately reduce the seat density in the aircraft in order to sell some seats at higher prices.

According to the ELFAA figures (European Low Fares Airline Association), the majority of the airlines that are members of the association operate homogenous aircraft fleet on shorthaul flights. The homogeneity varies from $41 \%$ (Air Baltic) to $100 \%$ (Ryanair). The average homogeneity value of European LCA is estimated at $92 \%$. For example, the homogeneity of FNSA fleet, which has the largest share in passenger air traffic on the four largest LCA markets in Europe (Alitalia, British Airways, Iberia and Lufthansa), is estimated from $67 \%$ (Lufthansa) to $100 \%$ (Iberia). Relations in number of aircraft, fleet type and aircraft order between FNSA and LCA can be seen in Table 2 .

The criteria that should be met by LCA in order for them to be considered as true LCA are the following: homogeneous aircraft fleet consisting of one aircraft model (more than $75 \%$ of requirement for LCA), the usage of secondary airports (over $50 \%$ of airports should be secondary for LCA needs), point-to-point flight network, no code sharing, one-way tariff per flight (only one-way tariffs or no more than one or two tariffs at any given moment), 
Table 2

Relation in the Number of Aircraft, Fleet Type and Aircraft Order of Traditional and Low-Cost Airlines

\begin{tabular}{|l|c|c|c|c|}
\hline \multicolumn{5}{|c|}{ FNSA } \\
\hline Airline & Year & $\begin{array}{c}\text { AC } \\
\text { type }\end{array}$ & $\begin{array}{c}\text { No. of } \\
\text { AC }\end{array}$ & $\begin{array}{c}\text { Order } \\
\text { AC }\end{array}$ \\
\hline Lufthansa & 1950 & 18 & 291 & 78 \\
\hline Austrian Airlines & 1957 & 8 & 39 & 0 \\
\hline Air France & 1933 & 16 & 250 & 36 \\
\hline KLM & 1920 & 11 & 116 & 1 \\
\hline Iberia & 1927 & 8 & 97 & 24 \\
\hline TAP Portugal & 1945 & 5 & 55 & 12 \\
\hline Turkish Airlines & 1933 & 15 & 190 & 61 \\
\hline British Airways & 1974 & 14 & 259 & 36 \\
\hline
\end{tabular}

\begin{tabular}{|c|c|c|c|c|}
\hline \multicolumn{5}{|c|}{ LCA } \\
\hline Airline & Year & $\begin{array}{l}\mathrm{AC} \\
\text { type }\end{array}$ & $\begin{array}{c}\text { No. of } \\
\text { AC }\end{array}$ & $\begin{array}{c}\text { Order } \\
\text { AC }\end{array}$ \\
\hline Ryanair & 1985 & 1 & 305 & 0 \\
\hline German Wings & 1997 & 1 & 34 & 4 \\
\hline easyJet & 1995 & 3 & 210 & 16 \\
\hline Wizz Air & 2003 & 1 & 39 & 76 \\
\hline Pegasus & 1990 & 3 & 40 & 79 \\
\hline Vueling & 2004 & 2 & 55 & 2 \\
\hline FlyBe & 1979 & 3 & 66 & 26 \\
\hline Norwegian AS & 1993 & 4 & 74 & 268 \\
\hline
\end{tabular}

Source: CAPA (2013)

one class in the cabin, no extra services on board (no in-flight service on a flight with the lowest or the highest tariff, no free charge for baggage registration with the highest or the lowest tariff, no FF program).

Briefly, here are listed thirteen criteria that should be met by LCA in order for them to be considered as airlines that satisfy the basic postulates of the low-cost model. The only LCA airline among the European top 20 that meets all the mentioned criteria is Ryanair. Among the "real" LCA there can also be listed Wizz Air, Blu Express, Bmibaby and Blue Air. Those airlines that meet eight out of the ten listed criteria can be called hybrid airlines with dominant characteristics of LCA, and these are: easyJet, Jet2, Corendon, Transavia, Vueling, Aer Lingus and Wind Jet. The third category is hybrid airlines with FNSA dominant features, which meet between four and seven criteria, and this category includes Norwegian, FlyBe and Germanwings. The last group, which meets up to three above mentioned criteria, can be seen as full-service airlines, and these are Air Berlin, Air Baltic, Niki, Meridiana fly and Air Italy.
As far as the other segment of possible reduction in operating costs is concerned - the usage of secondary airports - 20 ELFAA members have the average of $21 \%$; only three airlines meet the above mentioned requirement for the $50 \%$ usage (or more) of secondary airports (Wizz Air 58\%, FlyBe 53\% and Ryanair 50\%).

All European LCA, with the exception of Air Italy, offer only one-way tickets on their websites (without a discount on return flights). This is the only feature that differentiates some LCA from FNSA. On the other hand, all larger airlines except Ryanair offer enticing tariffs for frequent travelers. According to the percentage of the airlines that use secondary airports, it can also be concluded that most LCA use the same airports as FNSA, which additionally confirms the fact that the border line between LCA and FNSA is becoming thinner.

\section{Hybrid Models of Airlines}

The third chapter has shown that today it is difficult to determine the difference between different business models. Due to the dynamic airline market and an increasing number of airlines on the 
market (especially the smaller ones), airlines have started to implement a business model which by its characteristics does not match the decription of business models of airlines described in the second chapter. This has resulted in the emergence of a new model: a hybrid business model. Fig. 4 shows the evolution of the hybrid model in the example of three airlines (easyJet, JetBlue and Southwest) for the period between 2008 and 2010 (Sabre, 2011). This model is a combination of the savings methodology of costs that are practiced by LCA with the services, flexibility and route structure of FNSA. This business model is today maybe the most represented one on the airline market. It is characterized by a high standard of comfort and charging of all additional services. It has been accepted by business travelers and medium-class passengers. As the representatives of this model there can be mentioned JetBlue and Virgin Atlantic from the USA, as well as Air Berlin and Bmibaby from Europe. The example of long-haul airline that has successfully implemented this model is Air Asia.

Air Berlin is a typical example of an airline which has changed its business model from a charter to a hybrid airline, thus it can be placed in the FNSA group in line with the service it offers. In order to reduce its dependence on the largest German tour operators, Air Berlin, as the airline which was a charter airline until the mid-1990's, introduced a flight offer toward tourist destinations only before the competition did the same, and thus it has become the largest tourist airline. In order to enlarge the offer of its flights and become less dependent on seasonality, in 2002 Air Berlin set up City Shuttle (now called Euroshuttle), the service of low-cost transport that operates from a large number of the airports in Germany towards the key destinations such as London, Rome, Milan, Vienna and Zürich. In 2006 and 2007 it took over DBA and LTU airlines, thus expanding their flight offer to the destinations within Germany and to part of long-haul flights for tourism purposes. Unlike basic LCA, Air Berlin offers transfer flights from its hubs Berlin, Düsseldorf, Nuremberg and Palma de Mallorca, as well as the full service level on board (food, beverages, entertainment, FF program, etc.).

Another example of a typical hybrid airline is Aer Lingus. This is a former Irish national FNSA which offered full service on its flights from Dublin and Shannon to Europe, and it was connected by long-haul flights with the USA. The large competition on both markets has resulted in significant losses. This has led to a big change in a business model. Today Aer Lingus offers low-cost flights from Dublin to the main European airports that simultaneously board flights with a full service and two passenger classes on the flights to North America.

Part of cargo airlines has started offering the services of passenger transport in a way that they use convertible "Qucik Change" aircraft. The example of this is TNT Airways. The airline is based in Liege, and in its fleet it has one Boeing 737-300QC for the purpose of charter passenger transport, which enables the airline the maximum usage of its aircraft in a way that it performs passenger transport at day and cargo transport at night. Another example of an airline that operates in the same way is ASL, which has in its fleet Boeing 737s and transports mail at night, while being used for charter transport at day.

The fact that not only have LCA taken over the FNSA business model is proved by the example of traditional airlines FlyBe and Intersky which have taken over the very low tariff model from LCA.

Hybid airlines mostly operate on short-haul routes lasting three hours at minimum. Unlike 


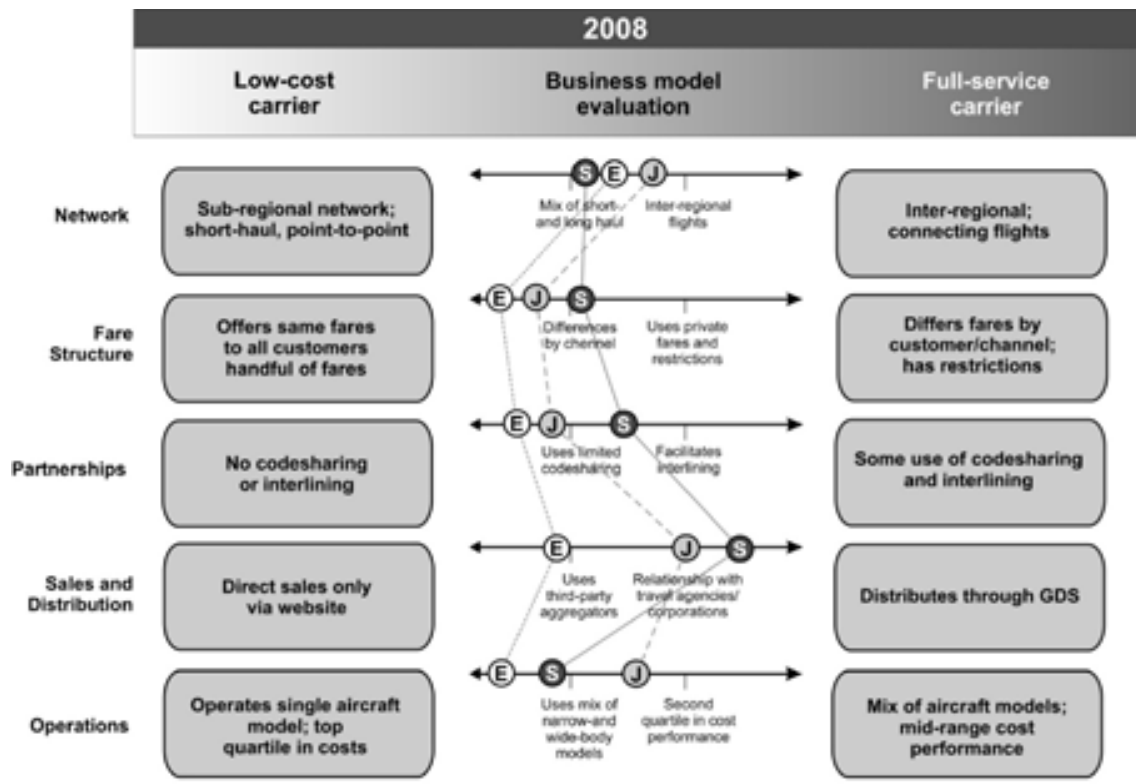

(E) easyjet (1) Jetilue $\mathbf{S}$ southwest

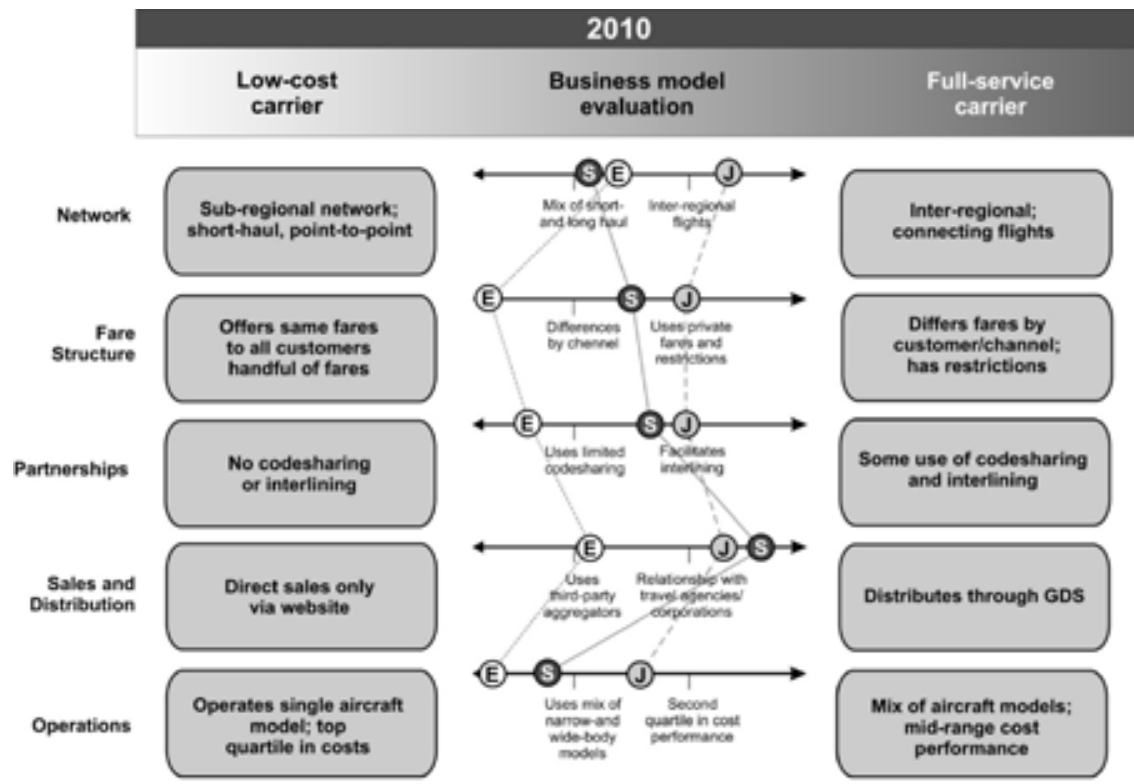

Fig. 4

Features of the Hybrid Model for Three Airlines in the Period 2008-2010

Source: Sabre (2011) 
the LCA basic model, the aircraft of such airlines offer more leg space; the seats are covered in leather; the cabin light has more quality, two passeneger clasess are offered at extra charge, entertainment offer is larger, food and beverages are available at extra charge (with some airlines they are included in the ticket price) as well as WiFi and FF program (Kurth, 2008). In addition to all this, some hybrid airlines have signed contracts on the cooperation with large airlines, thus expanding their flight network and serving to the large airlines as a good way for transfering passengers. Fig. 5 shows the characteristics of the hybrid model, i.e. the basic features that this model has taken over from LCA and FNSA business models.

\section{Conclusion}

The problems faced by all air carriers, such as the increasing fuel prices and airport taxes, as well as the increased competition on the aviation market, have led to the creation of hybrid airline business model that combines the best features of the LCA and FNSA business models. The increased operating costs will make a difference between business models smaller and smaller; ticket prices will be increasing with the service increase on board, which will continue to be attractive to business travelers, and less for the "leisure" ones. This model has been widely accepted and it combines cost savings methodology which is a characteristic of the LCA base model, with service, flexibility, and en-route structure of FNSA business model. The emergence of this model does not imply the disappearance of the already established business models of traditional and low-cost airlines from the market, but due to the adjustment to new market conditions, it is certain that in the near future there will be more airlines which will base its development strategy on the features of the hybrid business model. LCA will still remain the dominant carrier in a point-to-point network model for the destinations up to three hours of flight, even though there are some

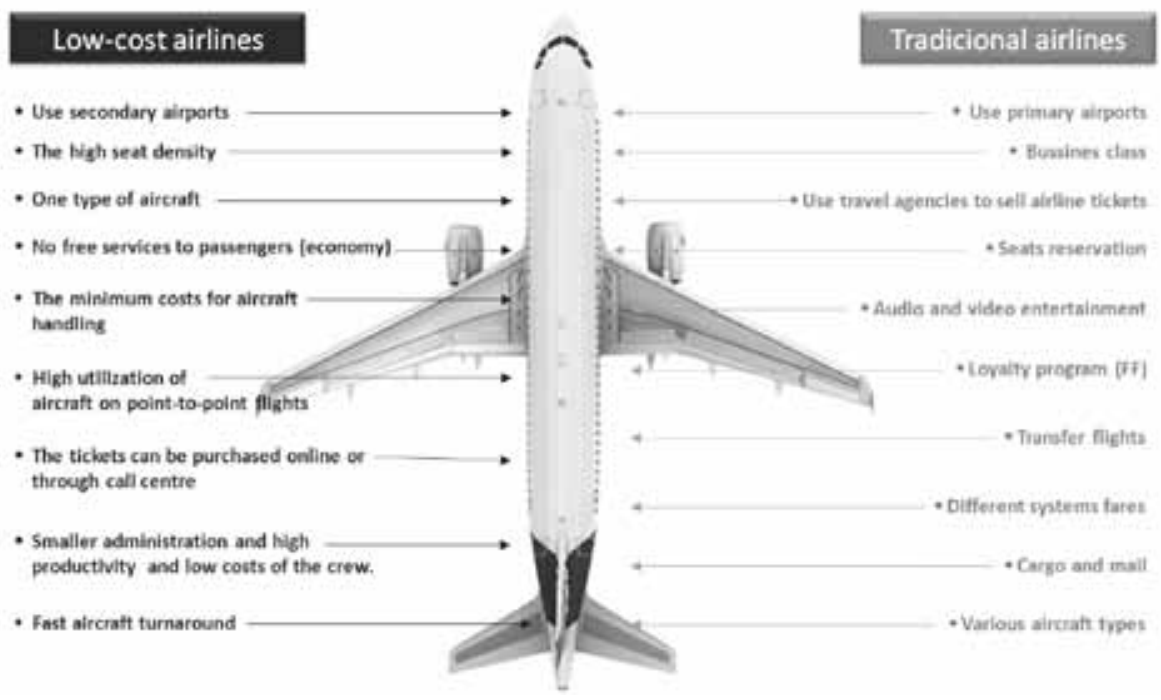

Fig. 5

The Characteristics of the Hybrid Model Based on the Characteristics of the LCA and FNSA Model Source: Štimac et al. (2012) 
indications of opening long-haul flights, also based on the hybrid air trasnport model, which should introduce further competitiveness to the already weakened group of network air carriers on the global level.

\section{References}

Centre for Aviation (CAPA) and Innovata. 2013. Available from Internet: <http://centreforaviation.com/>.

Deutsches Zentrum für Luft- und Raumfahrt e.V. (DLR). 2008. Topical Report: Airline Business Models. Available from Internet: <http://ec.europa.eu/transport/modes/ air/doc/abm_report_2008.pdf $>$.

Doganis, R. 2007. The airline business. Second edition, Routledge, USA. 307 p.

Gillen, D.; Gados, A. 2008. Airlines within airlines: Assessing the vulnerabilities of mixing business models, Research in Transportation Economics, 24(2008): 25-35.

Hamsathul, H.K. 2012. Airline Managenment Critical Rewiew of LCC VS Legacy Carrier. Available from Internet: <http://pgdalatm.nalsar.ac.in/projects/ ATM\%20II\%20LCC\%20vs\%20Legacy.pdf>.

Klophaus, R.; Conrady, R.; Fichert, F. 2012. Low cost carriers going hybrid: Evidence from Europe, Journal of Air Transport Management, 23(2012): 54-58.

Kurth, W. 2008. A Review of Regional Growth and Sustainability in the LCC Market. In Proceedings of the 22nd Annual Geneva International Aviation Forum, Aircraft Finance \& Commercial Aviation, MBA Workshop.

Sabre Airline Solutions. 2011. The Evolution of the Airline Business Model. Available from Internet: <http://www. sabreairlinesolutions.com/images/uploads/Hybrid Model_Brochure.pdf $>$.
Štimac, I.; Vince, D.; Vidović, A. 2012. Efect of Economic Crisis on the Changes of Low-Cost Carriers Business Models. In Proceedings of the 15th International Conference on Transport Science ICTS 2012.

Vidović, A.; Mihetec, T.; Steiner, S. 2012. Low-Cost Airlines Traffic Evolution in South-East Europe, Journal of Society for Development of Teaching and Business Processes in New Net Environment in B\&H, 7(1): 369-375.

\section{RAZVOJ POSLOVNIH MODELA NISKOTARIFNIH VAZDUHOPLOVNIH PREVOZILACA}

\section{Andrija Vidović, Igor Štimac, Damir Vince}

Sažetak: Globalna ekonomska kriza koja potresa sve industrije, pa tako i vazduhoplovnu industriju, primorala je vazduhoplovne prevozioce na prilagođavanje svojih poslovnih modela postojećim tržišnim zahtevima. Niskotarifni vazduhoplovni prevozioci, koji su se do početka ekonomske krize u većini slučajeva pridržavali baznog niskotarifnog modela poslovanja, su prilagodili svoje modele poslovanja tako da su implementirali segmente poslovnih modela tradicionalnih prevozilaca i na taj način stvorili hibride između niskotarifnog i tradicionalnog modela poslovanja. U radu je prikazano istraživanje koje ima za cilj da utvrdi u kojoj su meri niskotarifni vazduhoplovni prevozioci prilagodili svoj poslovni model hibridnom modelu poslovanja.

Ključne reči: niskotarifni vazduhoplovni prevozioci, poslovni model, hibridna strategija. 